\title{
Ocena jakości i odporności erozyjnej powłok natryskiwanych łukowo
}

\author{
Evaluation of the quality and erosion \\ resistance of arc sprayed coatings
}

\section{Streszczenie}

W artykule przedstawiono wyniki badań odporności erozyjnej powłok natryskiwanych łukowo wybranymi stopami typu Fe-Cr-Ti-Si-Mn, Fe-Cr-B-Si-Mn, Ni-Cr-Mo-Fe$\mathrm{Nb}$, Ni-WC-Cr-B-C oraz nano stopem na osnowie żelaza wzmacnianym wydzieleniowo węglikiem boru Fe-Si-MnCr-Mo-Nb-W-B, na płyty ze stali niestopowej ASTM A516, Grade 55 przeznaczonej do pracy w podwyższonej temperaturze. Do natryskiwania łukowego zastosowano najnowszej generacji urządzenie spawalnicze Eutronic Arc Spray 4 zapewniające wysoką stabilność przebiegu procesu oraz użyto druty proszkowe metaliczne EuTronic Arc 502, EuTronic Arc 547, EuTronic Arc 595, EuTronic Arc 599 i EnDOtec DO*390N o średnicy 1,6 mm. Natryskiwano łukowo powłoki o grubości około $0,8 \mathrm{~mm}$, odznaczające się zróżnicowaną twardością oraz odpornością na zużycie erozyjne.

Słowa kluczowe: natryskiwanie łukowe, powłoki natryskiwane łukowo, odporność na zużycie erozyjne

\section{Abstract}

The article presents the results of the study on erosion resistance of arc sprayed coatings made of selected alloys such as Fe-Cr-Ti-Si-Mn, Fe-Cr-B-Si-Mn, Ni-Cr-Mo-Fe$\mathrm{Nb}$, Ni-WC-Cr-B-C, and also nano alloy based on the iron matrix, strengthened by precipitations of boron carbide Fe-Si-Mn-Cr-Mo-Nb-W-B, on plates made of unalloyed steel ASTM A516, Grade 55 designed for for operation at elevated temperature. The latest generation of welding device Eutronic Arc Spray 4 for arc spraying was applied in the investigations, which ensure high stability of the process. Cored metallic wires such as EuTronic Arc 502, EuTronic Arc 547, EuTronic Arc 595, EuTronic Arc 599 i EnDOtec DO*390N with the diameter of $1,6 \mathrm{~mm}$ were used as the additional material. The coating produced by arc spraying were approx. 0,8 $\mathrm{mm}$ thick and had different hardness as well as different erosion wear resistance.

Keywords: Arc spray process, Arc spray coatings, Erosion wear resistance

\section{Wstęp}

W ostatnich latach metalizacja natryskowa uległa znacznej popularyzacji i dynamicznemu rozwojowi, dzięki zastosowaniu coraz bardziej zaawansowanych technicznie źródeł ciepła oraz nowych niestosowanych dotąd ma-

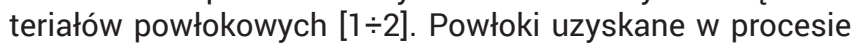
natryskiwania cieplnego często są ekonomicznie uzasadnionym rozwiązaniem wielu problemów występujących

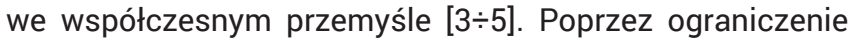
zużycia danego elementu zmniejsza się zarówno koszt jego użytkowania w jednostce czasu, podobnie jak intensywność uszkodzeń. Dodatkowo zwiększenie trwałości zmniejsza zawodność urządzenia w jego prawidłowym działaniu. Współcześnie, metodami natryskiwania cieplnego możliwe jest wykonanie wysokiej jakości powłok nanostrukuralnych np. na częściach silników samochodowych wykonanych ze stopów glinu, na stopach miedzi przeznaczonych na śruby napędowe jednostek pływających, powłok o dużej twardości, biokompatybilności, odporności na ścieranie, kawitację, poślizg, korozję, czy też powłok o określonych parametrach termicznych (tzw. Thermal Barier Coatings) lub gradientowej zmianie własności. Zużywanie się mechanizmów i części maszyn można skutecznie ograniczać ale nie da się go zupełnie wyeliminować. Istotnym procesem zużycia jest erozja, czyli zjawisko niszczenia powierzchni materiałów w wyniku wielokrotnych udarów strugi cieczy, gazu lub wyładowań elektrycznych. Zużyciu erozyjnemu ulega 8\% elementów maszyn, a zużyciu spowodowanemu jednoczesnym oddziaływaniem ścierania, erozji i kawitacji aż $14 \%$ [6]. Erozja jest bardzo niekorzystnym zjawiskiem ponieważ wywołuje degradację powierzchni materiałów w sposób trudny do przewidzenia na etapie projektowania. Zużycie erozyjne występuje w przypadku, gdy element maszyny jest ścierany przez strumień cząstek mineralnych, posiadających określoną energię kinetyczną. W zależności od rodzaju cząsteczek wywołujących erozję można wyróżnić: zużycie erozyjne w strumieniu cząstek ciał stałych, zużycie erozyjne w strumieniu cieczy zawierających cząstki ciała stałego (zużycie hydrościerne) oraz zużycie erozyjne

Dr inż. Artur Czupryński, dr inż. Aleksander Lisiecki - Politechnika Śląska, Katedra Spawalnictwa, dr inż. Agnieszka Kurc-Lisiecka - Wyższa Szkoła Biznesu w Dąbrowie Górniczej, Katedra Transportu Szynowego.

Autor korespondencyjny/Corresponding author. artur.czuprynski@polsl.pl 
w strumieniu cieczy (zużycie hydroerozyjne) [7]. Erozja jest zjawiskiem które bardzo często występuje w transporcie pneumatycznym i w silnikach samolotowych, a wspólne działanie erozji oraz kawitacji, można zauważyć w przypadku turbin wodnych, rurociągów oraz na powierzchni silnikowych tulei cylindrowych.

Głównymi skutkami erozji są straty ekonomiczne, które wynikają z konieczności wymiany i regeneracji urządzenia. W przemyśle lotniczym zużycie erozyjne może spowodować bezpośrednie zagrożenie dla życia pasażerów. Erozja materiałów powoduje zmianę geometrii elementów, co skutkuje skróceniem ich trwałość. Jednym ze sposobów zapobiegania zużycia w wyniku działania erozji jest nanoszenie powłok o odpowiedniej odporności erozyjnej.

\section{Cel i przebieg badań}

Celem przeprowadzonych badań było zbadanie i porównanie odporności erozyjnej powłok natryskiwanych łukowo, drutami proszkowymi metalicznymi EuTronic Arc 502, EuTronic Arc 547, EuTronic Arc 595, EuTronic Arc 599 i EnDOtec DO $390 \mathrm{~N}$ o średnicy $1,6 \mathrm{~mm}$, tablica I, na płyty wykonane ze stali niestopowej ASTM A516, Grade 55 przeznaczonej do pracy w podwyższonej temperaturze, tablica II. W oparciu o PN-EN ISO 14923:2005 [8] oraz wstępnie ustalone optymalne parametry procesu, dla każdego ze stosowanych materiałów dodatkowych, przeprowadzono próby natryskiwania łukowego powłok o grubości ok. 0,8 mm. Próby wykonano w pozycji naściennej na stanowisku produkcyjnym wyposażonym w urządzenie do natryskiwania łukowego EuTronic Arc Spray 4 oraz ręczny pistolet do natryskiwania Gun 4, rysunek 1 . Płyty stalowe o wymiarach 200×200×10 mm bezpośrednio przed procesem natryskiwania poddano śrutowaniu i wstępnie podgrzano palnikiem gazowym do temperatury około $40^{\circ} \mathrm{C}$. a)
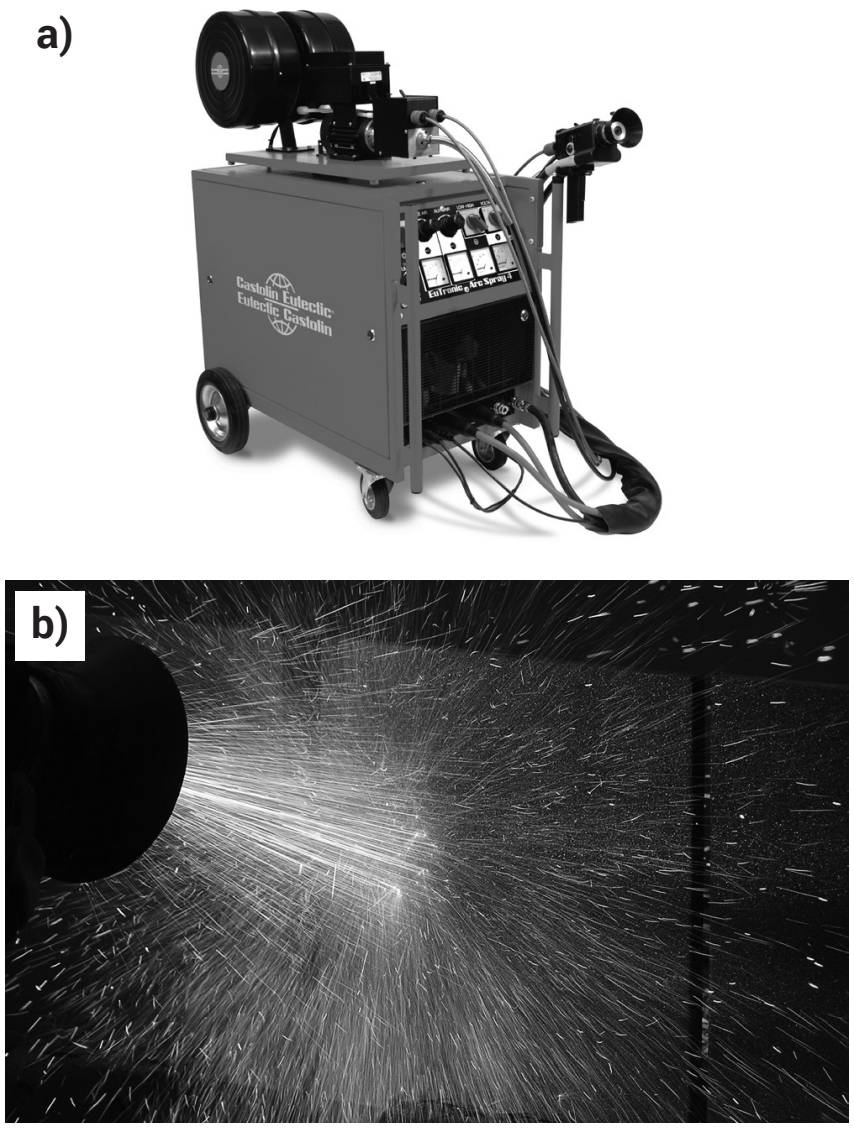

Rys. 1. Urządzenie do natryskiwania łukowego EuTronic Arc Spray 4 wyposażone w ręczny pistolet Gun 4 oraz przebieg procesu natryskiwania płyt próbnych

Fig. 1. The device for arc spraying EuTronic Arc Spray 4 equipped with handheld torch Gun 4 and a view of the process of arc spraying of test plates

Tablica I. Oznaczenie, skład chemiczny, twardość, gęstość i parametry natryskiwania łukowego próbek do badań odporności na zużycie erozyjne Table I. Designation, chemical composition, hardness, density and parameters of arc spraying of the samples for erosion wear tests

\begin{tabular}{|c|c|c|c|c|}
\hline \multirow[b]{2}{*}{$\begin{array}{l}\text { Oznaczenie } \\
\text { spoiwa }\end{array}$} & \multirow[b]{2}{*}{$\begin{array}{l}\text { Skład chemiczny oraz zmierzona } \\
\text { twardość i gęstość powłoki }\end{array}$} & \multicolumn{3}{|c|}{ Parametry natryskiwania } \\
\hline & & $\begin{array}{l}\text { Natężenie } \\
\text { prądu, A }\end{array}$ & Napięcie łuku, V & $\begin{array}{l}\text { Odległość pistoletu } \\
\text { od natryskiwanej } \\
\text { blachy, mm }\end{array}$ \\
\hline $\begin{array}{l}\text { EuTronic Arc } \\
\quad 502\end{array}$ & $\begin{array}{c}\mathrm{Fe}-15,0 \div 20,0 \% \mathrm{Cr}-2,5 \div 3,5 \% \mathrm{Ti} \\
-1,0 \div 1,5 \% \mathrm{Si}-<0,5 \div 1,5 \% \mathrm{Mn} \\
\text { Twardość powłoki: } 63 \mathrm{HRC} \\
\text { Gęstość powłoki: } 6,50 \mathrm{~g} / \mathrm{cm}^{3}\end{array}$ & 200 & 35,0 & 180 \\
\hline $\begin{array}{l}\text { EuTronic Arc } \\
\quad 547\end{array}$ & 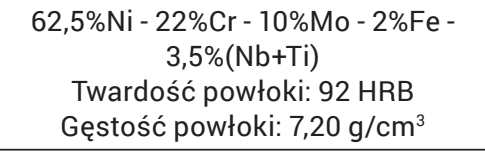 & 200 & 30,0 & 180 \\
\hline $\begin{array}{l}\text { EuTronic Arc } \\
\quad 595\end{array}$ & $\begin{array}{c}\text { Fe - } 25,0 \div 29,0 \% \mathrm{Cr}-3,0 \div 4,0 \% \mathrm{~B}- \\
1,0 \div 2,0 \% \mathrm{Si}-1,0 \div 2,0 \% \mathrm{Mn} \\
\text { Twardość powłoki: } 60 \mathrm{HRC} \\
\text { Gęstość powłoki: } 6,70 \mathrm{~g} / \mathrm{cm}^{3}\end{array}$ & 200 & 33,0 & 180 \\
\hline $\begin{array}{c}\text { EuTronic Arc } \\
599\end{array}$ & $\begin{array}{c}\text { Ni - WC - Cr - B - C } \\
\text { (szczegółowy skład chemiczny } \\
\text { zastrzeżony przez producenta) } \\
\text { Twardość osnowy: } 550 \mathrm{HV}(52 \mathrm{HRC}) \\
\text { Twardość WC: } 2400 \mathrm{HV} \\
\text { Gęstość powłoki: } 8,85 \mathrm{~g} / \mathrm{cm}^{3}\end{array}$ & 200 & 30,0 & 180 \\
\hline $\begin{array}{l}\text { EnDOTec } \\
\text { DO*390N }\end{array}$ & $\begin{array}{c}\mathrm{Fe}-<5 \% \mathrm{C}-<2,0 \% \mathrm{Si}-<5,0 \% \mathrm{Mn} \\
--<20,0 \% \mathrm{Cr}-<10,0 \% \mathrm{Mo}-<10,0 \% \mathrm{Nb}- \\
<10,0 \% \mathrm{~W}-<5,0 \% \mathrm{~B} \\
\text { Twardość powłoki: } 69 \mathrm{HRC} \\
\text { Gęstość powłoki: } 6,50 \mathrm{~g} / \mathrm{cm}^{3}\end{array}$ & 160 & 30,0 & 180 \\
\hline
\end{tabular}


Tablica II. Skład chemiczny blachy natryskiwanej łukowo drutami proszkowymi metalicznymi i blachy HARDOX 400 - materiału odniesienia w badaniach odporności na zużycie erozyjne

Table II. The chemical composition of steel plate substrate which was arc sprayed by the cored metallic wires and composition of the HARDOX 400 steel - reference material used comparison of erosion wear tests

\begin{tabular}{|c|c|c|c|c|c|c|c|c|c|}
\hline Oznaczenie blach & $\mathrm{C}$ & $\mathrm{Mn}$ & $\mathrm{Si}$ & $\mathrm{P}$ & $\mathrm{S}$ & $\mathrm{Cr}$ & $\mathrm{Ni}$ & $\mathrm{B}$ & $\mathrm{Mo}$ \\
\hline ASTM A516 Gr. 55 & 0,18 & 0,9 & 0,4 & 0,035 & 0,035 & - & & - & - \\
\hline HARDOX 400 & 0,14 & 1,6 & 0,7 & 0,025 & 0,010 & 0,50 & 0,25 & 0,004 & 0,25 \\
\hline
\end{tabular}
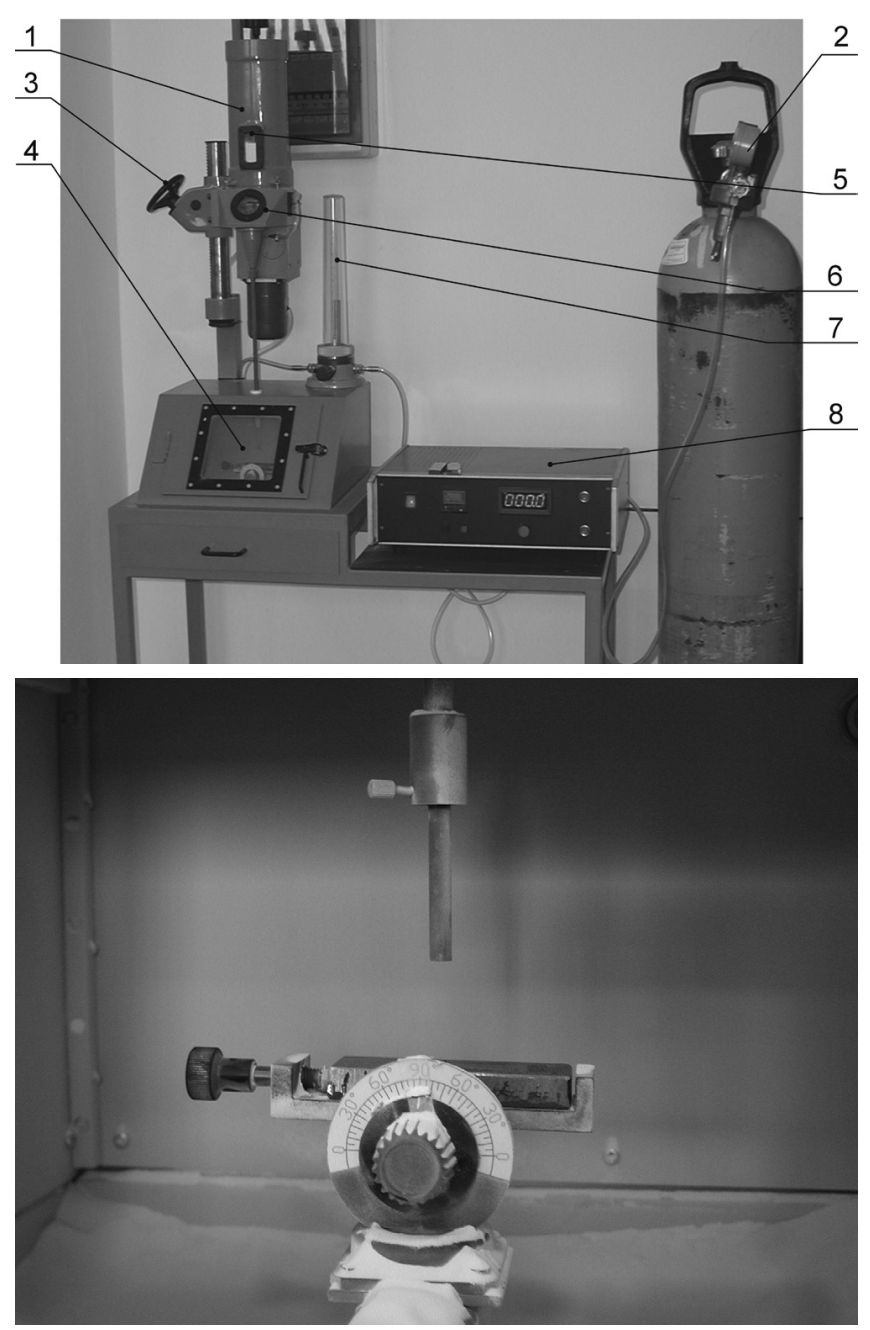

Rys. 2. Stanowisko do badań odporności na zużycie erozyjne zgodnie z normą ASTM G 76-2: a) widok ogólny: 1 - zbiornik na erodent, 2 - reduktor butli z powietrzem, 3 - pokrętło regulujące odległość dyszy od powierzchni próbki, 4 - komora pomiarowa urządzenia strumieniowo-powietrznego, 5 - okienko wizyjne do sprawdzania poziomu erodentu w zbiorniku, 6 - okienko wizyjne do sprawdzania ciągłości podawania erodentu do strumienia powietrza, 7 - rotametr, 8 - zespół sterowania i regulacji, b) widok wnętrza komory pomiarowej urządzenia strumieniowo-powietrznego

Fig. 2. The stand for erosion wear tests in accordance to ASTM G 76-2 standard: a) a general view: 1 - the container for erodent, 2 - the pressure reducer of the air cylinder, 3 - the knob for adjusting the distance between the nozzle tip and the test surface, 4 - The chamber of the erosion tester, 5 - the inspection window for checking of the erodent level, 6 - the inspection window for checking the erodent flow into the air jet, 7 - rotameter, 8 - control unit, 9 - the inner view of the chamber

Ilościowej oceny odporności na zużycie erozyjne powłok natryskiwanych łukowo wybranymi stopami typu Fe-Cr-TiSi-Mn (EuTronic Arc 502), Fe-Cr-B-Si-Mn (EuTronic Arc 547), Ni-Cr-Mo-Fe-Nb (EuTronic Arc 595), Ni-WC-Cr-B-C (EuTronic Arc 599) oraz nano stopem na osnowie żelaza wzmacnianym wydzieleniowo węglikiem boru Fe-Si-Mn-Cr-Mo-Nb-W-B
(EnDOTec DO*390N) oraz stali HARDOX 400 dokonano w oparciu o normę ASTM G 76-2 [9], rysunek 2, wykonano badania odporności erozyjnej na próbkach o wymiarach $70 \times 25 \times 10 \mathrm{~mm}$.

Przed przystąpieniem do badań odporności na zużycie erozyjne aparaturę badawczą, zgodnie z zaleceniami normy ASTM G 76-2, poddano kalibracji ustalając natężenie przepływu strumienia czynnika erozyjnego tlenek aluminium (Al203) oraz erozyjny ubytek masy na próbce wzorcowej wykonanej ze stali AISI 1020. Badania odporności na zużycie erozyjne powłok natryskiwanych łukowo wytypowanymi drutami proszkowymi metalicznymi oraz stali HARDOX 400 przeprowadzono dla kąta padania czynnika erozyjnego względem powierzchni próbki wynoszącego $90^{\circ}$, tablicy III. Weryfikacji grubości oraz oceny porowatości wykonanych powłok dokonano na podstawie badań mikroskopowych zgładów metalograficznych trawionych w nitalu, rysunek 3 i 4.

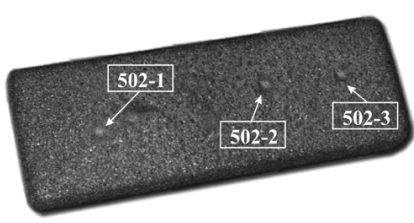

EuTronic Arc 502 (Fe-Cr-Ti-Si-Mn)

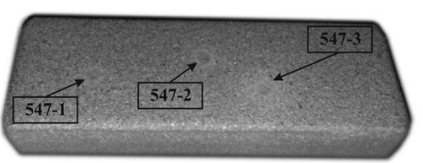

EuTronic Arc 547 (Fe-Cr-B-Si-Mn)

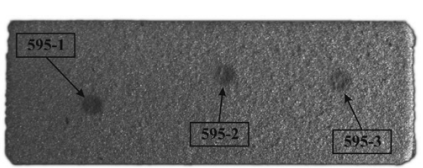

EuTronic Arc 595 (Ni-Cr-Mo-Fe-Nb)

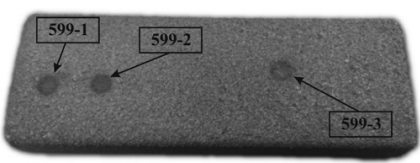

EuTronic Arc 599 (Ni-WC-Cr-B-C)
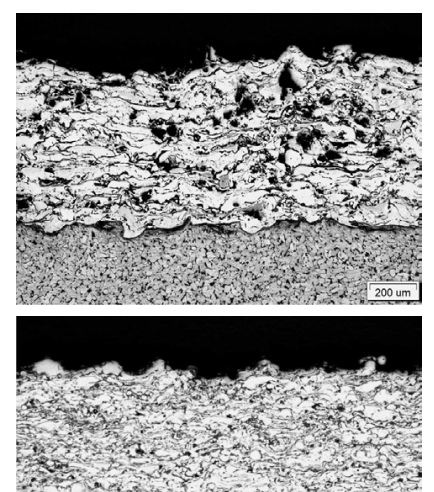

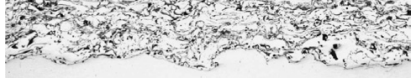
$200 \mathrm{um}$
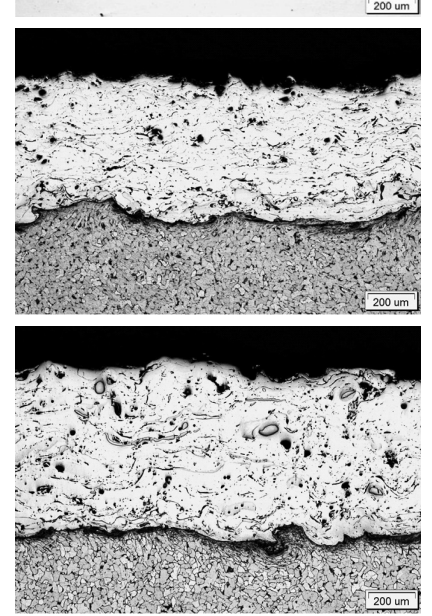

Rys. 3. Widok próbek po badaniach mikroskopowych oraz badaniach odporności erozyjnej powłok natryskiwanych łukowo wytypowanymi drutami proszkowymi metalicznymi oraz stali HARDOX 400 przeprowadzonych dla kąta padania erodentu wynoszącego $90^{\circ}$

Fig. 3. A view of samples after microscope observations and erosion wear test of arc sprayed coatings by selected cored metallic wires and the HARDOX 400 steel conducted at the erodent incident angle of $90^{\circ}$ 


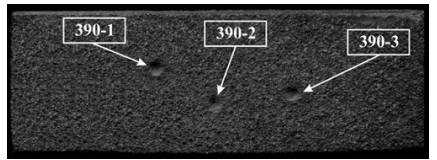

EuTronic DO*390N

(Fe-Si-Mn-Cr-Mo-Nb-W-B)

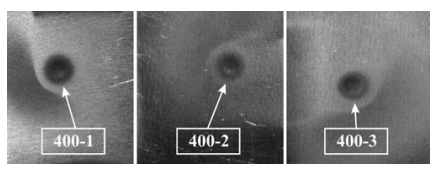

HARDOX 400

Rys. 4. Widok próbek po badaniach mikroskopowych oraz badaniach odporności erozyjnej powłok natryskiwanych łukowo wytypowanymi drutami proszkowymi metalicznymi oraz stali HARDOX 400 przeprowadzonych dla kąta padania erodentu wynoszącego $90^{\circ}$

Fig. 4. A view of samples after microscope observations and erosion wear test of arc sprayed coatings by selected cored metallic wires and the HARDOX 400 steel conducted at the erodent incident angle of $90^{\circ}$

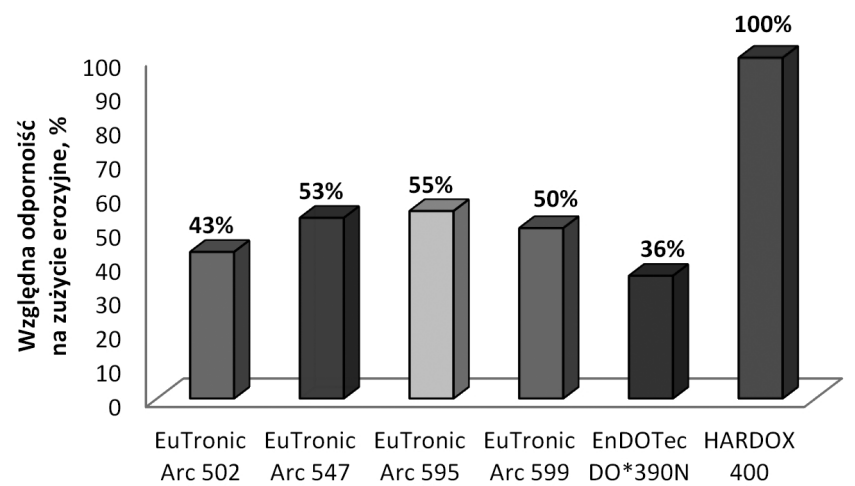

Nazwa powłoki/stali

Rys. 5. Porównanie odporności erozyjnej powłok natryskiwanych łukowo wytypowanymi drutami proszkowymi metalicznymi oraz stali HARDOX 400 przeprowadzonej dla kąta padania erodentu wynoszącego $90^{\circ}$

Fig. 5. The comparison of erosion wear resistance of arc sprayed coatings by selected cored metallic wires and the HARDOX 400 steel conducted at the erodent incident angle of $90^{\circ}$

Tablica III. Wyniki badań odporności na zużycie erozyjne powłok natryskiwanych łukowo wytypowanymi drutami proszkowymi metalicznymi w odniesieniem do odporności na zużycie erozyjne stali HARDOX 400 przeprowadzonych zgodnie z normą ASTM G 76-2

Table III. The results of erosion wear tests of arc sprayed coatings by selected cored metallic wires compared to the erosion resistance of HARDOX 400 steel, conducted in accordance to ASTM G 76-2 standard

\begin{tabular}{|c|c|c|c|c|c|c|c|}
\hline $\begin{array}{l}\text { Oznaczenie } \\
\text { próbki }\end{array}$ & Numer próbki & $\begin{array}{l}\text { Ubytek } \\
\text { masowy, g }\end{array}$ & $\begin{array}{l}\text { Szybkość } \\
\text { erozji, g/min }\end{array}$ & $\begin{array}{c}\text { Ubytek } \\
\text { objętościowy, } \\
\mathrm{mm}^{3}\end{array}$ & $\begin{array}{c}\text { Odporność } \\
\text { na zużycie } \\
\text { erozyjne, } \\
0,001 \mathrm{~mm}^{3} / \mathrm{g} \\
\text { wg } \\
\text { ASTM G76-2 }\end{array}$ & $\begin{array}{c}\text { Średnia } \\
\text { odporność } \\
\text { zużycie } \\
\text { erozyjne, } \\
0,001 \mathrm{~mm}^{3} / \mathrm{g}\end{array}$ & $\begin{array}{l}\text { Względna } \\
\text { odporność } \\
\text { erozyjna* }\end{array}$ \\
\hline \multirow{3}{*}{$\begin{array}{l}\text { EuTronic } \\
\text { Arc } 502\end{array}$} & $502-1$ & 0,0123 & 0,00123 & 1,89231 & 93,44729 & \multirow{3}{*}{94,00} & \multirow{3}{*}{0,43} \\
\hline & $502-2$ & 0,0125 & 0,00125 & 1,92308 & 94,96676 & & \\
\hline & $502-3$ & 0,0123 & 0,00123 & 1,89231 & 93,44729 & & \\
\hline \multirow{3}{*}{$\begin{array}{l}\text { EuTronic } \\
\text { Arc } 547\end{array}$} & $547-1$ & 0,0109 & 0,00109 & 1,51389 & 74,75995 & \multirow{3}{*}{77,05} & \multirow{3}{*}{053} \\
\hline & $547-2$ & 0,0117 & 0,00117 & 1,62500 & 80,24691 & & \\
\hline & $547-3$ & 0,0111 & 0,00111 & 1,54167 & 76,13169 & & \\
\hline \multirow{3}{*}{$\begin{array}{l}\text { EuTronic } \\
\text { Arc } 595\end{array}$} & 595-1 & 0,0097 & 0,00097 & 1,44776 & 71,49438 & \multirow{3}{*}{74,69} & \multirow{3}{*}{0,55} \\
\hline & $595-2$ & 0,0105 & 0,00105 & 1,56716 & 77,39082 & & \\
\hline & $595-3$ & 0,0102 & 0,00102 & 1,52239 & 75,17966 & & \\
\hline \multirow{3}{*}{$\begin{array}{l}\text { EuTronic } \\
\text { Arc } 599\end{array}$} & $599-1$ & 0,0145 & 0,00145 & 1,63842 & 80,90953 & \multirow{3}{*}{81,10} & \multirow{3}{*}{0,50} \\
\hline & $599-2$ & 0,0147 & 0,00147 & 1,66102 & 82,02553 & & \\
\hline & $599-3$ & 0,0144 & 0,00144 & 1,62712 & 80,35154 & & \\
\hline \multirow{3}{*}{$\begin{array}{l}\text { EnDOTec } \\
\text { DO*390N }\end{array}$} & $390-1$ & 0,0148 & 0,00148 & 2,27692 & 112,4406 & \multirow{3}{*}{111,93} & \multirow{3}{*}{0,36} \\
\hline & $390-2$ & 0,0147 & 0,00147 & 2,26154 & 111,6809 & & \\
\hline & $390-3$ & 0,0145 & 0,00147 & 2,26154 & 111,6809 & & \\
\hline \multirow{3}{*}{ HARDOX 400} & $400-1$ & 0,0065 & 0,00065 & 0,82592 & 40,78623 & \multirow{3}{*}{40,79} & \multirow{3}{*}{1,0} \\
\hline & $400-2$ & 0,0066 & 0,00066 & 0,83863 & 41,41371 & & \\
\hline & $400-3$ & 0,0064 & 0,00064 & 0,81321 & 40,15875 & & \\
\hline
\end{tabular}

Uwaga: Szybkość erozji, [g/min] = ubytek masowy próbki, [g] / czas ekspozycji, [min]; Ubytek objętościowy [mm³] = ubytek masowy próbki, [g] / gęstość powłoki $\left[\mathrm{g} / \mathrm{mm}^{3}\right]$; Odporność na zużycie erozyjne, $0,001 \mathrm{~mm} 3 / \mathrm{g}=$ ubytek objętościowy próbki, $\left[\mathrm{mm}^{3}\right] / \mathrm{całkowita} \mathrm{masa}^{2}$ erodentu użytego w próbie, [g]. Parametry próby erozyjnej: prędkość erodentu - $702 \mathrm{~m} / \mathrm{s}$, temperatura $20{ }^{\circ} \mathrm{C}$, erodent - $\mathrm{Al}_{2} \mathrm{O}_{3}$, rodzaj gazu

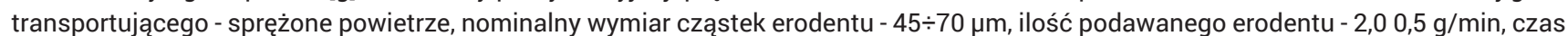
próby - $10 \mathrm{~min}$, odległość pomiędzy dyszą a próbką - $10 \mathrm{~mm}$, gęstość powłoki natryskiwanej przyjęto z tabl. 1, gęstość stali HARDOX $400-7,87 \mathrm{~g} / \mathrm{cm} 3$, masa erodentu użytego w próbie - 20,25 g. * - wynik odniesiono do próbek wykonanych z płyty stalowej HARDOX 400 


\section{Wnioski}

Natryskiwanie łukowe, drutami proszkowymi z rdzeniem metalicznym gatunku EuTronic Arc 502 (Fe-Cr-Ti-Si-Mn), EuTronic Arc 547 (Fe-Cr-B-Si-Mn), EuTronic Arc 595 (Ni-Cr-Mo-Fe-Nb), EuTronic Arc 599 (Ni-WC-Cr-B-C) oraz EnDOtec DO*390N (Fe-Si-Mn-Cr-Mo-Nb-W-B) o średnicy 1,6 mm, stali niestopowej ASTM A516, Grade 55, zapewnia wykonanie wysokiej jakości powłok o zróżnicowanej gęstości, tablica I. Największą gęstość $8,85 \mathrm{~g} / \mathrm{cm}^{3}$ odnotowano dla powłoki wykonanej spoiwem EuTronic Arc 599, a najmniejszą gęstość $6,50 \mathrm{~g} / \mathrm{cm}^{3}$ zmierzono dla powłok natryskiwanych drutami proszkowymi EuTronic Arc oraz 502EnDOtec DO*390N. Wszystkie powłoki charakteryzowały zróżnicowaną chropowatością, dużą równomiernością na całej powierzchni i w przybliżeniu jednakową grubością wynoszącą około $0,8 \mathrm{~mm}$.

Badanie wizualne prowadzone na zgładach metalograficznych prostopadłych do wykonanych powłok wykazały, że największą porowatością odznaczały się powłoki natryskiwane drutami proszkowymi EuTronic Arc 502 i EnDOtec DO*390N, ilość pustek występujących w powłokach była zbliżona, jednakże wielkość pustek zaobserwowanych w powłoce EnDOtec DO*390N była znacznie większa, rysunek 3. Minimalną ilość i wielkość pustek zidentyfikowano w powłoce wykonanej spoiwem EuTronic Arc 547. Powłoka natryskiwana nano stopem na osnowie żelaza wzmacnianym wydzieleniowo węglikiem boru Fe-Si-Mn-Cr-Mo-Nb-W-B (EnDOtec DO*390N) pomimo bardzo wysokiej twardości wynoszącej na powierzchni około 69 HRC odznaczała się najniższą odpornością na zużycie erozyjne wynoszącą 36\% odporności na zużycie erozyjne stali HARDOX 400. Podobnie jak powłoka natryskiwana łukowo spoiwem EuTronic Arc 502 (Fe-Cr-Ti-Si-Mn), która przy twardości powierzchni zewnętrznej wynoszącej 63 HRC wykazywała tylko nieznacznie wyższą odporność na zużycie erozyjne, tablica III, rysunek 4.

Odporność na zużycie erozyjne tej warstwy była o 7\% wyższa niż odporność na zużycie erozyjne powłoki EnDOtec DO*390N. Powłoki metalizowane łukowo drutami proszkowymi EuTronic Arc 547 oraz EuTronic Arc 599 wykazywały niemal dwukrotnie niższą odporność na zużycie erozyjne niż stal HARDOX 400. Najwyższą względną odpornością na zużycie erozyjne z pośród wszystkich badanych powłok wyróżniała się powłoka wykonana spoiwem EuTronic Arc 595, która przy twardości 60 HRC osiągnęła 55\% odporności na zużycie erozyjne stali HRDOX 400.

\section{Literatura}

[1] Poole Ch. P. Jr, Ownes F. J. Introduction to Nanotechnology, Wiley, 2003, Pages 1-8.

[2] Wilson M., Kanangara K., Smith G., Simmons M., Raguse B. Nanotechnology: Basic sciences and emerging technologies, Overseas Press, 2005.

[3]. Bobzin K., Wielage B., Drzeniek H.: Natryskiwanie cieplne - rozwój, potencjał, rynki, Przegląd Spawalnictwa, nr 9/2009, s. 4-10.

[4]. Dorfman M.R: Thermal spray processes. Advanced Materials \& Processes, vol. 160, Ohio 2002, 47-49.

[5]. Luding R., Thorpe R.: Electric Arc Spray Coatings Increase Cost And Reliability of Power Generation Systems, Advanced Materials \& Processes, vol. 171, Ohio 2013, 46-48.
[6] Adamiec P., Dziubiński J.: Wytwarzanie i właściwości warstw wierzchnich elementów maszyn transportowych, Wydawnictwo Politechniki Śląskiej. Gliwice 2005.

[7] Gierek A.: Zużycie Tribologiczne, Wydawnictwo Politechniki Śląskiej, Gliwice 2005

[8] PN-EN ISO 14923:2005 „Natryskiwanie cieplne -- Charakterystyka i badanie powłok natryskiwanych cieplnie".

[9] ASTM G 76-2 "Standard Test Method for Conducting Erosion Test by Solid Particle Impingement Using Gas Jets". 